\title{
ARTICLES
}

The Philosophy of Man as All-Embracing Philosophy EDWINA. BURTT The Divided Line and the Direction of Inquiry .... ROBERT S. BRUMBAUGH The Quarrel Between Philosophy and Poetry LASZLO VERSENYI

Plato's Cratylus: Dialogue as Revision HARRY BERGER, JR. A Pendulum Swing Theory of Islam ERNEST GELLNER Confirmation and the Natural Subject FRED SOMMERS Onotology and Mind-Body. Identity CHARLES CRITTENDEN Why the Problem of Other Minds LEON J. GOLDSTEIN

$\$ 8.00$ a year for individual subscribers; $\$ 10.00$ a year for institutional subscribers payable to The Philosophical Forum

\section{Department of Philosophy}

BOSTON UNIVERSITY, 232 Bay State Road, Boston, Massachusetts 02215

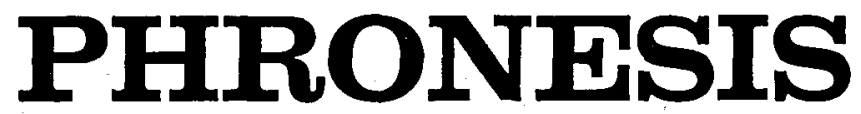

\section{A journal for ancient philosophy}

PHRONESIS appears twice a year and provides articles and studies in English, French, German and Latin by experts of international standing. Each issue contains 96 pages.

Managing editor: Prof. David J. Furley

Dept. of Classics

Princeton University, PRINCETON, N. J. USA

Subscription: Per annum Hfl. 25,00 (\$7.50)

Back-volumes are available

Publishers: ROYAL VANGORCUM LTD

ASSEN, The Netherlands 


\title{
PHILOSOPHY AND PHENOMENOLOGICAL RESEARCH
}

\section{AN INTERNATIONAL QUARTERLY}

\author{
Edited by MARVIN FARBER
}

in cooperation with a distinguished group of American and Foreign Scholars

Descriptive, analytic, critical, and historical articles representing the major contemporary trends in philosophy. In addition to papers on phenomenology, PPR published studies in a wide range of areas including ethics and value theory, metaphysics, aesthetics, logic, language, political, social, and religious philosophy, theory of knowledge, and the sciences.

Address all communications to Philosophy and Phenomenological Research

\section{State University of New York at Buffalo Buffalo, New York 14226}

Annual subscription rate, $\$ 9.00$ for libraries and institutions, $\$ 7.50$ for individuals; single copies $\$ 2.50$ and $\$ 2.00$ respectively, plus postage and handling on back issues only. Papers submitted for publication will not be returned unless accompanied by a self-addressed stamped envelope, or equivalent postage.

A circular listing the main contents of the Journal since 1940 will be sent upon request.

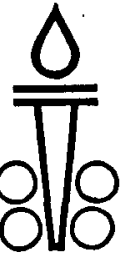

\section{THE PHILOSOPHER'S INDEX}

\section{An International Quarterly Index}

\section{To Philosophical Periodicals}

The Philosopher's Index is an up-to-date quarterly index of articles from more than one hundred and fifty major philosophy journals are related interdisciplinary publications. Articles are indexed by subject and author. Abstracts of the articles are published in each issue and are written by the authors of the articles. In addition, the Index contains a Book Review Index.

The Quarterly, Paperback, $\$ 20$ (Individuals: \$10)

Annual Cumulative Edition, Hardbound, \$25 (Individuals: \$15)

U.S. and Canada:

\section{THE PHILOSOPHER'S INDEX \\ BOWLING GREEN UNIVERSITY \\ BOWLING GREEN, OHIO 43403 USA}

Outside the U.S. and Canada:

D. REIDEL PUBLISHING COMPANY/DORDRECHT, HOLLAND 